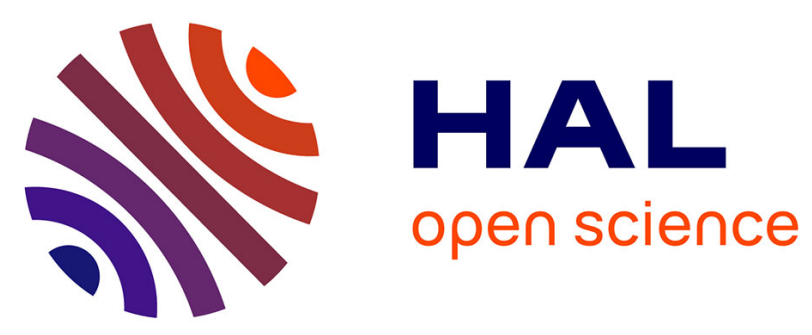

\title{
Cereal-legume intercropping modifies the dynamics of the active rhizospheric bacterial community
}

Elisa Taschen, Laurie Amenc, Estelle Tournier, Philippe Deleporte, Philippe

Malagoli, Joëlle Fustec, David Bru, Laurent Philippot, Laetitia Bernard

\section{- To cite this version:}

Elisa Taschen, Laurie Amenc, Estelle Tournier, Philippe Deleporte, Philippe Malagoli, et al.. Cereallegume intercropping modifies the dynamics of the active rhizospheric bacterial community. Rhizosphere, 2017, 3 (1), pp.191-195. 10.1016/j.rhisph.2017.04.011 . hal-01603314

\section{HAL Id: hal-01603314 https://hal.science/hal-01603314}

Submitted on 25 May 2020

HAL is a multi-disciplinary open access archive for the deposit and dissemination of scientific research documents, whether they are published or not. The documents may come from teaching and research institutions in France or abroad, or from public or private research centers.
L'archive ouverte pluridisciplinaire HAL, est destinée au dépôt et à la diffusion de documents scientifiques de niveau recherche, publiés ou non, émanant des établissements d'enseignement et de recherche français ou étrangers, des laboratoires publics ou privés. 


\section{Author's Accepted Manuscript}

Cereal-legume intercropping modifies the dynamics of the active rhizospheric bacterial community

E. Taschen, L. Amenc, E. Tournier, P. Deleporte, P. Malagoli, J. Fustec, D. Bru, L. Philippot, L. Bernard

Rhizosphere

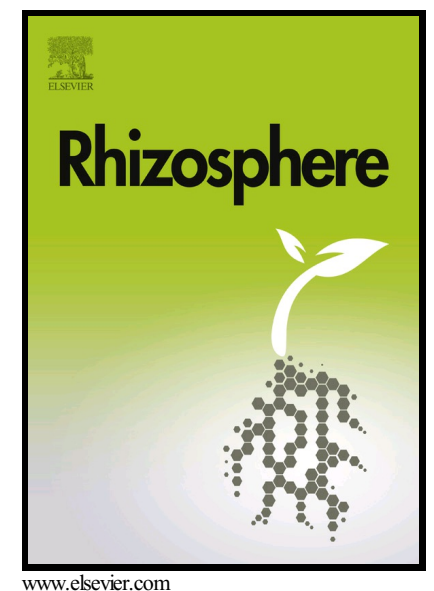

PII: S2452-2198(17)30026-5

DOI: $\quad$ http://dx.doi.org/10.1016/j.rhisph.2017.04.011

Reference: RHISPH55

To appear in: Rhizosphere

Received date: 2 February 2017

Revised date: 20 April 2017

Accepted date: 20 April 2017

Cite this article as: E. Taschen, L. Amenc, E. Tournier, P. Deleporte, P. Malagoli, J. Fustec, D. Bru, L. Philippot and L. Bernard, Cereal-legum intercropping modifies the dynamics of the active rhizospheric bacteria community, Rhizosphere, http://dx.doi.org/10.1016/j.rhisph.2017.04.011

This is a PDF file of an unedited manuscript that has been accepted fo publication. As a service to our customers we are providing this early version o the manuscript. The manuscript will undergo copyediting, typesetting, an review of the resulting galley proof before it is published in its final citable form Please note that during the production process errors may be discovered whic could affect the content, and all legal disclaimers that apply to the journal pertain 


\section{Cereal-legume intercropping modifies the dynamics of the active rhizospheric}

\section{bacterial community.}

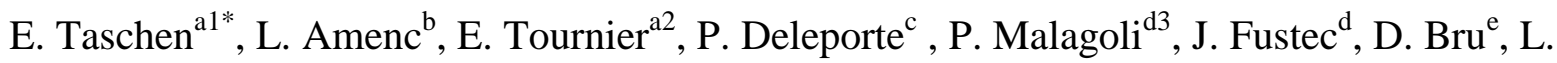
Philippot $^{\mathrm{e}}$, L. Bernard ${ }^{\mathrm{a}}$

${ }^{a}$ Institut de Recherche pour le Développement (IRD), UMR Eco\&Sols, 2 place Viala, 34060 Montpellier Cedex 1, France

${ }^{b}$ Institut National pour la Recherche Agronomique (INRA), UMR Eco\&Sols, 2 place Viala, 34060 Montpellier Cedex 1, France

${ }^{c}$ Centre international de Recherche Agronomique pour le développement (CIRAD), UMR Eco\&Sols, 2 place Viala, 34060 Montpellier Cedex 1, France

${ }^{d}$ Ecole Supérieure d'Agriculture, UR LEVA , SFR 4207 QUASAV, 55 rue Rabelais, 49007 Angers cedex, France.

${ }^{e}$ INRA, UMR 1347 Agroecologie, 17, rue Sully, B.V. 86510, 21065 Dijon Cedex France

*Corresponding author: Phone +33(0)499613036, Fax: +33(0)499612119, E-mail: elisa.taschen@inra.fr

\footnotetext{
${ }^{1}$ Present address : Institut National pour la Recherche Agronomique (INRA), UMR Eco\&Sols, 2 place Viala, 34060 Montpellier Cedex 1, France.

2 Present address: LSTM, UMR 113 Cirad/Inra/Ird/Sup-Agro/Um2, Campus international de Baillarguet, 34398 Montpellier Cedex 5, France.

${ }^{3}$ Present address: Université Clermont Auvergne, INRA, PIAF, F-63000 Clermont-Ferrand, France.
} 


\section{Abstract.}

We assessed the impact of intercropping on the microbial communities in the rhizosphere of wheat (Triticum turgidum L. ssp durum) and pea (Pisum sativum L.). Using a RNA based approach coupled with bacterial phylum specific real time PCR, we found that the active bacterial communities in the wheat-pea association were distinct from those in the rhizosphere when crops were cultivated solely. This first explorative study showed that intercropping induced a synergetic interaction, which modified the structure of active microbial communities associated with roots by reducing the representation of Alpha-Proteobacteria and Acidobacteria while promoting Actinobacteria. The latter phylum harbors many species identified as growth promoting bacteria, calling for further analyses to better understand their function for intercropped cultures.

Graphical abstract

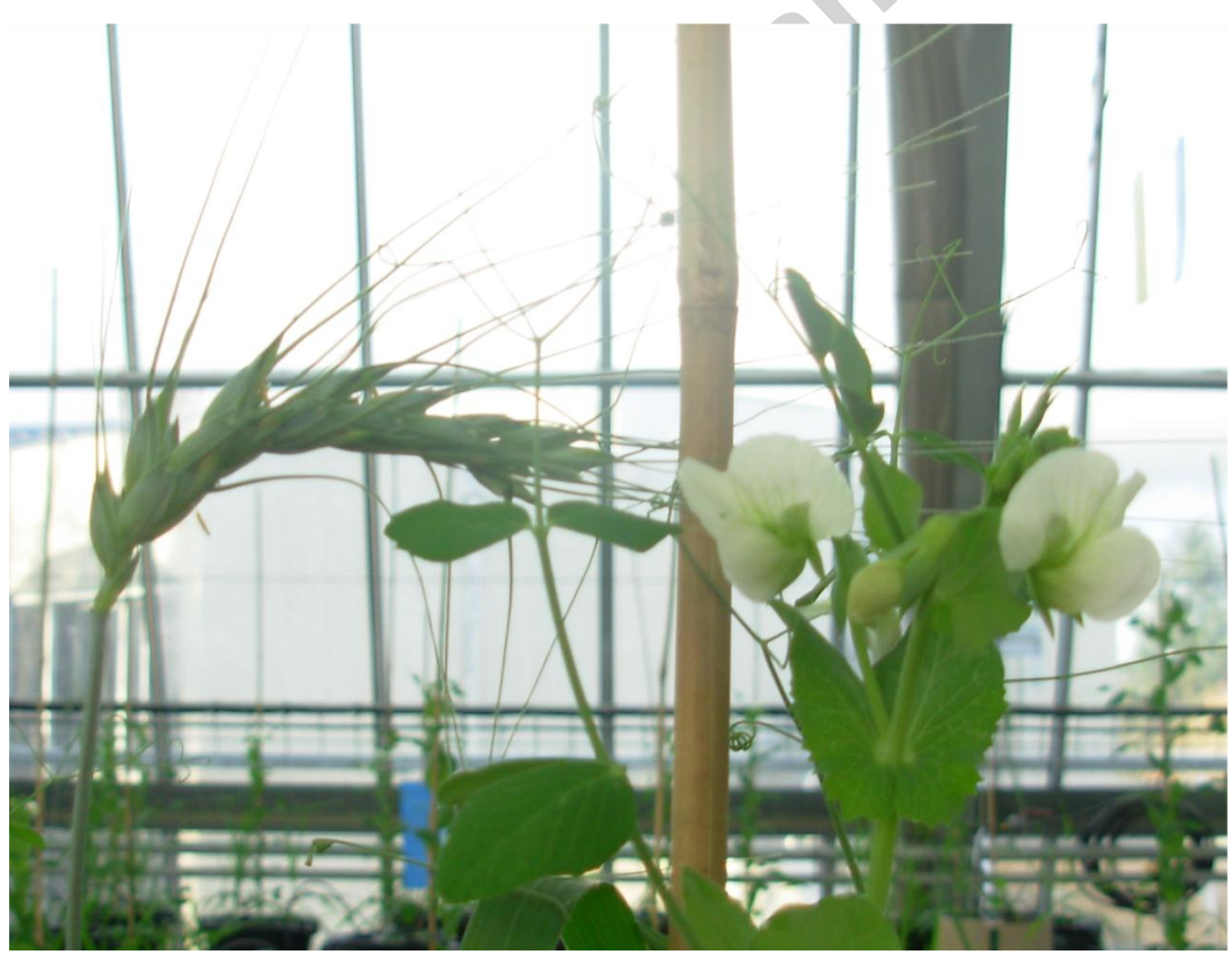


Wheat-pea intercropping revealed a distinct active bacterial community than those in the rhizosphere of sole crops, with a decrease in Proteobacteria and Acidobacteria in favor of Actinobacteria.

Key words: bacterial phyla, heterotrophic microbial communities, RNA, cDNA, quantitative PCR.

\section{Manuscript.}

Cereal-legume intercropping has been demonstrated to noticeably increase plant yield (Song et al. 2007b, Pelzer et al., 2012). The cereal being more competitive for soil inorganic N, the legume is forced to increase its symbiotic $\mathrm{N}_{2}$ fixation capacity (Hauggaard-Nielsen et al. 2003). In intermingled roots of intercrops, fixed nitrogen deposited to the soil by the legume belowground parts can benefit to the neighbouring plant (Fustec et al. 2011). Such plant-to-plant interactions, in this case possibly qualified as facilitation, can largely be driven by the rhizospheric microbial communities harboured by plants (Eisenhauer 2012). Free microorganisms in the rhizosphere are involved in several processes leading to nutrient mobilization, which are important for plant nutrition. Some of these processes are autotrophic ammonia oxidation, free $\mathrm{N}_{2}$ fixation, phytase and phosphatase activities, phosphorus solubilization, and use of energy-rich rhizodeposits to mine the recalcitrant soil organic matter for nutrients also defined as rhizospheric priming effect (Kuzyakov 2002). Most of these specialized processes are performed by a limited number of microbial taxonomic groups, such as denitrification carried out by less than $5 \%$ of cultured bacterial species in soil (Tiedje, 1994) or ammonia oxidation, restricted to a monophyletic group of $\beta$-proteobacteria (Kowalchuk and Stephen, 2001). Therefore modification of the microbial community structure can lead to changes in rhizospheric functioning. Structure and diversity of rhizospheric bacterial communities are specific to plant species (Kowalchuk et al. 2002) and varies with plant phenology (Houlden et al. 2008), largely driven by the quantity and quality of rhizodeposition 
(Marschner et al. 2004). As a consequence, the structure of rhizosphere microbial communities can be changed in one or both plant species, which in turn can modulate the intensity of microbial processes (Song et al. 2007a, 2007b; Yang et al. 2016). The aim of the present study was to determine whether intercropping could modifies the structure of free and active bacterial communities of a pea-wheat associations relative to the rhizosphere of sole plantings.

For that purpose, pea plant (Pisum sativum L.) and wheat plants (Triticum turgidum L. ssp durum) were cultivated solely (one pea plant; two wheat plants per pot) or intercropped (one pea + two wheat plants per pot) in $10 \mathrm{~kg}$ replicated soil pots in a greenhouse in Angers, France $\left(47^{\circ} 28^{\prime} 0^{\prime}, \mathrm{N}, 0^{\circ} 47^{\prime} 31^{\prime \prime} \mathrm{W}\right)$, at the end of year 2009 . To take into account seasonal patterns of nitrogen fixation of the pea (Jensen 1987), plants were harvested at three different stages of the pea development $(\mathrm{n}=4)$ : stage 1 (early)- end of vegetative stage of pea; stage 2 (medium)- $40 \%$ of the pea pods have reached their maximal length, and stage 3 (late) - pea pods maturity. At harvest, root adhering soil (considered as rhizopheric) was sampled by pooling roots of all plants grown in a same pot, and non-adhering soil was sampled as bulk soil. RNA was extracted from soil, quantified fluorometricaly, reverse-transcribed and 16S RNA genes were amplified by quantitative PCR using couples of primers specific to the 4 major bacterial phyla (Actinobacteria, Acidobacteria, Bacteroidetes and Firmicutes) and to the 3 classes within the Proteobacteria ( $\alpha, \beta, \gamma$-Proteobacteria). The relative abundance of each active phylum was calculated as the percentage of $16 \mathrm{~S}$ transcripts of individual phyla divided by the sum the $16 \mathrm{~S}$

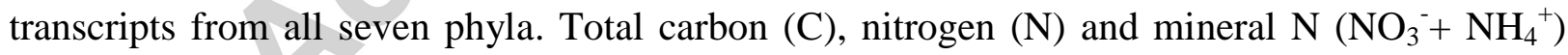
were also quantified. Data were analyzed by ANOVA, Tukey's post-hoc test, and principal component analyses. Experimental design, techniques used and statistical analyses are fully described in Appendix 1.

As expected, microbial activity was enhanced in the rhizosphere (Smalla et al., 2006), with a two-fold yield of RNA compared to the bulk soil due to the release of rhizodeposits as indicated by higher $\mathrm{C}$ and $\mathrm{N}$ content (Table 1 a.). Labile carbon shaped bacterial communities by 
stimulating well known Proteobacteria r-strategists (Fierer et al., 2007), while Actinobacteria, Acidobacteria and Firmicutes, adapted to the decomposition of complex compounds, were relatively more abundant in the b soil (Table 1 a.). But as shown by the total RNA yield and the relative abundance of the opportunist $\gamma$-Proteobacteria, rhizosphere effect was highest at early stage of plant growth and decreased over time (Table 1). This reflects the reduction of root exudation after flowering stage and/or the increase in root degeneration (Aulakh et al. 2001). This shift in the quality of rhizodeposits towards possibly higher $\mathrm{C} / \mathrm{N}$, (Gransee A \& Wittenmayer 2000), may have favored the persistence of other non-opportunistic bacteria, able to assimilate more chemically recalcitrant substrates (i.e., cellulose, lignin, or tannin-protein). These results support "the ecological coherence of high bacterial taxonomic ranks" (Philippot et al. 2010) and the reactiveness of RNA studies reflecting environmental changes at centimetric and short times scales.

The bacterial community in the rhizospheres of intercropped plants differed from both monocultures as demonstrated by the distinct segregation on the PCA of relative abundance of transcripts of the seven phyla (Fig.1). Further statistical analyses by ANOVA and post-hoc tests (Tukey's test; Appendix 1) showed that $\alpha$-Proteobacteria, Actinobacteria and Acidobacteria were significantly linked to the culture type. The $\alpha$-Proteobacteria were more abundant in the pea rhizosphere when grown solely than in the wheat (Table $1 \mathrm{~b}$.). This subgroup comprises the Rhizobiales order composed of well-known symbiotic nitrogen-fixing genera. Although many of its representatives have lost their capacities to infect legumes, they remain abundant in legume rhizospheres (Denison and Kiers 2004). Interestingly, intercropping with wheat appeared to slightly decrease their activity as the proportions of their transcripts were below those observed in the wheat rhizosphere alone. Acidobacterial transcripts accounted for a low proportion of the assemblages (below $10 \%$ ), probably because many members of this phylum are adapted to low $\mathrm{pH}\left(\mathrm{pH}_{\mathrm{H} 2 \mathrm{O}}\right.$ of the used soil = 8; Jones et al. 2009) and negatively correlated to total C and N, (Fierer et al. 2007; Dean et al. 2015). Legumes are known to acidify their 
rhizosphere during N2 fixation (Hinsinger et al. 2003); thus, pea may have lowered the rhizosphere soil $\mathrm{pH}$ and slightly stimulated the activity of Acidobateria at the microscale, which was significantly higher in pea than in the wheat monoculture.

Conversely to Acidobacteria, relative abundance of Actinobacteria was higher in the rhizosphere of wheat grown solely, than in pea and was even enhanced in intercropped cultures (Table 1). Previous studies showed that Actinobacteria were particularly abundant in wheat rhizosphere and roots as endophytic bacteria (Conn and Franco 2004). Many actinobacterial species are known to be plant pathogen-antagonist due to antibiotic release, production of bacterial and fungal cell-wall degrading enzymes and the production of multiple siderophores outcompeting pathogenic microbes for iron (Palaniyandi et al. 2013). The ability of certain species to degrade complex recalcitrant polycyclic aromatic molecules such as lignin (Větrovský et al. 2014), fix atmospheric $\mathrm{N}_{2}$ (Gtari et al. 2012), solubilize phosphorus and help for plant-mycorrhiza symbiosis confers to some Actinobacteria the valuable qualification as plant growth promoting microbes.

The present study indicated that under greenhouse conditions, intercropping was not a simple mix of both plant rhizospheres but induced a synergic interaction which modified active microbial community structure in the vicinity of roots. In natural alpine tundra, Dean et al. (2015) observed that plant neighborhood effect on root-associated bacteria was stronger than abiotic factor like soil $\mathrm{N}$ enrichment. As far as we know, the present study is the first report of such effect in associated cultured crops, identifying three main involved phyla. These results call for further analyses on the field, questioning how these modifications of rhizospheric bacterial communities impact nutrient fluxes towards crops, and in fine, contribute to better yields. 


\section{Acknowledgements}

This work has been funded by the French "Agence Nationale pour la Recherche" (Systerra program, PerfCom project, ANR-08-STRA-11h).

\section{Appendix 1 - Complements of methods}

\section{Experimental design}

Pisum sativum L. cv. Frisson and Triticum turgidum L. ssp. durum cv. LA1823 were grown in ten liter pots. Pots were filled with a sandy clay loam soil ( $24.8 \%$ clay, $43.6 \%$ silt, $35 \%$ sand, 91 mg P kg${ }^{-1}$ (Olsen), $394 \mathrm{mg} \mathrm{K} \mathrm{kg}{ }^{-1}, 193 \mathrm{mg} \mathrm{Mg} \mathrm{kg}{ }^{-1}, 72 \mathrm{mg} \mathrm{NO}_{3}{ }^{-} \mathrm{kg}^{-1}, 1.2 \mathrm{mg} \mathrm{NH}_{4}{ }^{+} \mathrm{kg}^{-1}$, average $\mathrm{pH}_{\mathrm{H} 2 \mathrm{O}}$ 8), passed through a 2-mm sieve and inoculated with Rhizobium leguminosarum bv. viciae (P221 strain) to guarantee sufficient biological $\mathrm{N}$ fixation for adequate plant development. Seeds were pre-germinated in moist paper. Durum wheat was sown a fortnight before pea. Pre-germinated seeds were transplanted into pots following the different modalities: i) 1 pea plant alone (Pea), ii) one pea and two wheats in the same pot (Intercropping), and iii) 2 wheats in the same pot (Wheat). Plants were watered to maintain soil moisture between 15-20\% and no fertilizer was supplied. Control pots without plants were included to the experiment. For each modality, plants were harvested at three different stages $(n=4)$ : i) end of vegetative stage of pea (Early, Stage 1), ii) $40 \%$ of the pea pods have reached their maximal length (Medium, Stage 2), and iii) pea pods maturity (Late, Stage 3). In all, the experiment lasted three month (Sowing : $18^{\text {th }}$ of September; Last harvest $: 16^{\text {th }}$ of December).

\section{Sampling methods}

At harvest, roots adhering soil of all plants of a same pot was sampled as the composite rhizosphere soil, and non-adhering soil was sampled as controls. To guarantee RNA conservation, sub-samples of all soil samples were immediately stored at $-80^{\circ} \mathrm{C}$ for molecular analyses, while the rest was dried at $70^{\circ} \mathrm{C}$ for further chemical analyses.

\section{Chemical analyses}


Samples of dry fine powder of rhizospheric soils were prepared for $\mathrm{N}$ and $\mathrm{C}$ elementary analysis

(EA 3000 EuroVector, University of Caen, France; Eksperiandova et al. 2011. Mineral $\mathrm{N}\left(\mathrm{NO}_{3}{ }^{-}\right.$

$+\mathrm{NH}_{4}{ }^{+}$) has also been quantified on samples using a continuous flow SKALAR analyzer, following methods described in Houba et al. (1988).

\section{Quantitative PCR on bacterial phyla}

RNA was extracted from rhizospheric soil samples by the combination of the FastDNA SPINTM kit for soil and the RNaide $\mathrm{Kit}^{\mathrm{TM}}$ (MP Biomedical, Santa Ana, California) following the protocol described in (Tournier et al. 2015). RNA was quantified using Quan-i $\mathrm{T}^{\mathrm{TM}}$ Ribo Green RNA Assay Kit (Molecular Probes, Calsbard, New Mexico) and stored at $-80^{\circ} \mathrm{C}$ prior to reverse transcription. Reverse transcription (ARN to ADNc) was performed using $150 \mathrm{ng}$ of extracted RNA with the Verso cDNA kit and random nonamer (Abgene, Epsom, UK). RNA was extracted from soil samples stored at $-80^{\circ} \mathrm{C}$. RNA was quantified using Quan-i $\mathrm{T}^{\mathrm{TM}}$ Ribo Green RNA Assay Kit (Molecular Probes, Calsbard, New Mexico). The numbers of 16S rRNA gene copies belonging to the 4 major bacterial phyla (Actinobacteria, Acidobacteria, Bacteroidetes and Firmicutes) and to the 3 classes within the Proteobacteria ( $\alpha, \beta, \gamma$-Proteobacteria) was quantified in $10 \mathrm{ng}$ of cDNA template by real time quantitative PCR with specific primers couples (Table 1, Appendix 1). qPCR reactions were carried out in an C1000 CFX96 Real-Time system thermocycler (BioRad, Hercules, USA). Each $10 \mu 1$ reaction volume contained $5 \mu$ l of SYBE Green (ABgene, Epsom, UK), $1 \mu \mathrm{l}$ of the forward and reverse taxon-specific primers at $10 \mu \mathrm{M}(20 \mu \mathrm{M}$ for the degenerated primers, ie, $\alpha, \gamma$-Proteobacteria), $0.5 \mu 1$ of T4gp32 (MP Biomedical, Santa Ana, California) and $0.5 \mu \mathrm{l}$ of $\mathrm{H} 2 \mathrm{O}$ for $2 \mu \mathrm{l}$ of DNA template at $5 \mathrm{ng} . \mu \mathrm{l}^{-1}$. PCR conditions were $15 \mathrm{~min}$ at $95^{\circ} \mathrm{C}$, followed by 35 cycles of $95^{\circ} \mathrm{C}$ for 15 seconds (s), $30 \mathrm{~s}$ at the annealing temperature (specific for each primer couple, see Table 1, Appendix 1), and $72^{\circ} \mathrm{C}$ for 30 s. Each plate included duplicate reactions per DNA sample and triplicate for standard set. Standard curves were obtained by serial dilution $\left(10^{8}-10^{3}\right)$ of linearized plasmids containing cloned 16S rRNA genes representing each taxa (Table 2, Appendix 1). qPCR efficiency varied 
between $83.5 \%$ and $93.8 \%$ and melting curve analysis was conducted to confirm that the fluorescence signal originated from specific PCR products.

Table 1 Specific primers couples and PCR conditions.

${ }^{1}$ Fierer N, Jackson JA, Vilgalys R, Jackson RB. Assessment of soil microbial community structure by use of taxon-specific quantitative PCR assays. Applied and environmental microbiology 2005; 71(7): 4117-4120.

${ }^{2}$ Mühling M, Woolven-Allen J, Murrell JC, \& Joint I. Improved group-specific PCR primers for denaturing gradient gel electrophoresis analysis of the genetic diversity of complex microbial communities. The ISME journal 2008; 2(4): 379-392.

PCR conditions :

\begin{tabular}{cclc}
\hline Taxon & Primers & \multicolumn{1}{c}{ Sequence (5'-3') } & PCR conditions \\
\hline a-proteobacteria $^{1}$ & Eub338 & ACT CCT ACG GGA GGC AGC AG & A \\
& Alfa685 & TCT ACG RAT TTC ACC YC TAC & B \\
B-proteobacteria & Eub338 & ACT CCT ACG GGA GGC AGC AG & B \\
& Bet680 & TCA CTG CTA CAC GYG & \\
y-proteobactéria $^{2}$ & Gamma395F & CMA TGC CGC CGC GTG TGT GAA & B \\
& Gamme871R & ACT CCC CAG GCG GTC DAC TTA & \\
Acidobacteria $^{1}$ & Acid31 & GAT CCT GGC TCA GAA TC & B \\
& Eub518 & ATT ACC GCG GCT GCT GG & \\
Actinobacteria $^{1}$ & Actino235 & CGC GGC CTA TCA GCT TGT TG & A \\
& Eub518 & ATT ACC GCG GCT GCT GG & \\
Bacteroïdetes $^{1}$ & Cfb319 & GTA CTG AGA CAC GGA CCA & A \\
& Eub518 & ATT ACC GCG GCT GCT GG & \\
Firmicutes $^{1}$ & Lgc353 & GCA GTA GGG AAT CTT CCG & B \\
& Eub518 & ATT ACC GCG GCT GCT GG & \\
& & &
\end{tabular}

A: $95^{\circ} \mathrm{C}, 15 \mathrm{~min}$, and 35 cycles at $95^{\circ} \mathrm{C}$ for $15 \mathrm{~s}, 60^{\circ} \mathrm{C}$ for $30 \mathrm{~s}, 72^{\circ} \mathrm{C}$ for $30 \mathrm{~s}, 80^{\circ} \mathrm{C}$ for $30 \mathrm{~s}$ B: $95^{\circ} \mathrm{C}, 15 \mathrm{~min}$, and 35 cycles at $95^{\circ} \mathrm{C}$ for $15 \mathrm{~s}, 55^{\circ} \mathrm{C}$ for $30 \mathrm{~s}, 72^{\circ} \mathrm{C}$ for $30 \mathrm{~s}, 80^{\circ} \mathrm{C}$ for $30 \mathrm{~s}$ 
Table 2 Bacterial strains used as references for the standard curves. Each strain was cultivated as recommended on DSMZ (www.dsmz.de). DNA was extracted as previously detailed in the manuscript, with a supplemental purification step using Gene Clean Turbo kit (MP Biomedical, Santa Ana,USA).

\begin{tabular}{lllc}
\hline \multicolumn{1}{c}{ Taxon } & \multicolumn{1}{c}{ DSM n } & \multicolumn{1}{c}{ Species } & 16S copy numbers \\
\hline$\alpha$-proteobacteria & DSM 5172 & Agrobacterium tumefaciens & 1 \\
$\beta$-proteobacteria & DSM 2839 & Cupriavidus metallidurans & 2 \\
p-proteobacteria & DSM 1117 & Pseudomonas aeruginosa & 4 \\
Actinobacteria & DSM 12829 & Arthrobacter chlorophenolines & 5 \\
Acidobacteria & DSM 11244 & Acidobacterium capsulatum & 1 \\
Bacteroidetes & DSM 13855 & Salinibacter ruber & 1 \\
Firmicutes & DSM 10 & Bacillus subitilis & 10 \\
\hline
\end{tabular}

\section{Statistical analyses}

Variation of soil characteristics and relative abundance of each phylum were analyzed by generalized linear models (ANOVA) and Tukey's post-hoc test (in R, using 'stat' package) independently, first on soil types (AS: Adhering soil, NAS: Non-Adhering soil), and second on the adhering soil, crossing the phenology stage (Early, E; Medium, M; Late, L) and the culture type (Pea, P; Wheat, W; Intercropping, I) factor. For further visual insights into shifts in the bacterial community structure, a principal component analysis (PCA) was performed in R (using 'stats' and 'factoextra' packages) on the relative abundance of each phylum in rhizospheric soil samples, and non-adhering soil samples were added as supplemental individuals. The culture type (wheat, pea, and intercropping) and plant sampling stages (early, medium, late) were integrated as qualitative supplementary variables. RNA recovery yields, total carbon $(\mathrm{C})$ and nitrogen $(\mathrm{N})$, measured in soil, were considered as quantitative supplementary variables.

\section{References}

Eksperiandova LP, Fedorov OI, Stepanenko NA, Estimation of metrological characteristics of the element analyzer EuroVector EA-3000 and its potential in the single-reactor CHNS mode Microchemical Journal 2011; 99: 235-238.

Houba V, van der Lee JJ, Novozamsky I, Walinga I, Soil Analysis Procedures, Department of Soil Science and Plant Analysis (1988), Wageningen, The Netherlands. 
Tournier E, Amenc L, Pablo A-L et al. Modification of a commercial DNA extraction kit for safe and rapid recovery of DNA and RNA simultaneously from soil, without the use of harmful solvents. MethodsX 2015; 2:182-191.

\section{References}

Aulakh, M. S., Wassmann, R., Bueno, C., Kreuzwieser, J., \& Rennenberg, H. (2001).

Characterization of root exudates at different growth stages of ten rice (Oryza sativa L.) cultivars. Plant Biology, 3(02), 139-148.

Conn, V. M., \& Franco, C. M. (2004). Analysis of the endophytic actinobacterial population in the roots of wheat (Triticum aestivum L.) by terminal restriction fragment length polymorphism and sequencing of $16 \mathrm{~S}$ rRNA clones. Applied and environmental microbiology, 70(3), 1787-1794.

Dean, S. L., Farrer, E. C., Porras- Alfaro, A., Suding, K. N., \& Sinsabaugh, R. L. (2015). Assembly of root- associated bacteria communities: interactions between abiotic and biotic factors. Environmental microbiology reports, 7(1), 102-110.

Denison, R. F., \& Kiers, E. T. (2004). Lifestyle alternatives for rhizobia: mutualism, parasitism, and forgoing symbiosis. FEMS Microbiology Letters, 237(2), 187-193.

Eisenhauer, N. (2012). Aboveground-belowground interactions as a source of complementarity effects in biodiversity experiments. Plant and Soil, 351(1-2), 1-22.

Fierer, N., Bradford, M. A., \& Jackson, R. B. (2007). Toward an ecological classification of soil bacteria. Ecology, 88(6), 1354-1364.

Fustec, J., Lesuffleur, F., Mahieu, S., \& Cliquet, J. B. (2011). Nitrogen rhizodeposition of legumes. In Sustainable Agriculture Volume 2 (pp. 869-881). Springer Netherlands.

Gtari, M., Ghodhbane-Gtari, F., Nouioui, I., Beauchemin, N., \& Tisa, L. S. (2012). Phylogenetic perspectives of nitrogen-fixing actinobacteria. Archives of microbiology, 194(1), 3-11.

Gransee, A., \& Wittenmayer, L. (2000). Qualitative and quantitative analysis of water- soluble root exudates in relation to plant species and development. Journal of Plant Nutrition and Soil Science, 163(4), 381-385.

Hauggaard-Nielsen, H., Ambus, P., \& Jensen, E. S. (2003). The comparison of nitrogen use and leaching in sole cropped versus intercropped pea and barley. Nutrient Cycling in Agroecosystems, 65(3), 289-300. 
Hinsinger, P., Plassard, C., Tang, C., \& Jaillard, B. (2003). Origins of root-mediated pH changes in the rhizosphere and their responses to environmental constraints: a review. Plant and soil, 248(1-2), 43-59.

Houlden, A., Timms-Wilson, T. M., Day, M. J., \& Bailey, M. J. (2008). Influence of plant developmental stage on microbial community structure and activity in the rhizosphere of three field crops. FEMS Microbiology Ecology, 65(2), 193-201.

Jones, R. T., Robeson, M. S., Lauber, C. L., Hamady, M., Knight, R., \& Fierer, N. (2009). A comprehensive survey of soil acidobacterial diversity using pyrosequencing and clone library analyses. The ISME journal, 3(4), 442-453.

Kowalchuk, G. A., \& Stephen, J. R. (2001). Ammonia-oxidizing bacteria: a model for molecular microbial ecology. Annual Reviews in Microbiology, 55(1), 485-529.

Kowalchuk, G. A., Buma, D. S., de Boer, W., Klinkhamer, P. G., \& van Veen, J. A. (2002). Effects of above-ground plant species composition and diversity on the diversity of soilborne microorganisms. Antonie Van Leeuwenhoek, 81(1-4), 509.

Marschner, P., Crowley, D., \& Yang, C. H. (2004). Development of specific rhizosphere bacterial communities in relation to plant species, nutrition and soil type. Plant and soil, 261(1), 199-208.

Palaniyandi, S. A., Yang, S. H., Zhang, L., \& Suh, J. W. (2013). Effects of actinobacteria on plant disease suppression and growth promotion. Applied microbiology and biotechnology, 97(22), 9621-9636.

Pelzer, E., Bazot, M., Makowski, D., Corre-Hellou, G., Naudin, C., Al Rifaï, M., et Carrouée, B. (2012). Pea-wheat intercrops in low-input conditions combine high economic performances and low environmental impacts. European Journal of Agronomy, 40, 3953.

Philippot, L., Andersson, S. G., Battin, T. J., Prosser, J. I., Schimel, J. P., Whitman, W. B., \& Hallin, S. (2010). The ecological coherence of high bacterial taxonomic ranks. Nature Reviews Microbiology, 8(7), 523-529.

Smalla, K., Sessitsch, A., \& Hartmann, A. (2006). The Rhizosphere:'soil compartment influenced by the root'.

Song, Y. N., Marschner, P., Li, L., Bao, X. G., Sun, J. H., \& Zhang, F. S. (2007). Community composition of ammonia-oxidizing bacteria in the rhizosphere of intercropped wheat (Triticum aestivum L.), maize (Zea mays L.), and faba bean (Vicia faba L.). Biology and Fertility of Soils, 44(2), 307-314.

Song, Y. N., Zhang, F. S., Marschner, P., Fan, F. L., Gao, H. M., Bao, X. G., ... \& Li, L. (2007). Effect of intercropping on crop yield and chemical and microbiological properties in rhizosphere of wheat (Triticum aestivum L.), maize (Zea mays L.), and faba bean (Vicia faba L.). Biology and Fertility of Soils, 43(5), 565-574.

Tiedje J.M. (1994). Denitrifiers. In Methods of Soil Analysis. Part 2. SSSA Book Series 5. Weaver, R.W., Angle, J.S., and Bottomley, P.S. (eds). Madison, 1994, WI: SSSA, pp. 245-267. 
Větrovský, T., Steffen, K. T., \& Baldrian, P. (2014). Potential of cometabolic transformation of polysaccharides and lignin in lignocellulose by soil Actinobacteria. PLoS One, 9(2), e89108

Yang, Z., Yang, W., Li, S., Hao, J., Su, Z., Sun, M., ... \& Zhang, C. (2016). Variation of bacterial community diversity in rhizosphere soil of sole-cropped versus intercropped wheat field after harvest. PloS one, 11(3), e0150618.

Table 1 ANOVA (p-values) and Tukey's post-hoc test (significant differences are indicated by letters, p.values $<0.05$ ) on the soil characteristics and relative abundance of each phylum of the active bacterial community depending on a. soil type (R: Rhizospheric soil, B: Bulk soil) and b. plant phenology stage (Early, E; Medium, M; Late, L) and culture type (Pea, P; Wheat, W; Intercropping, I). The interaction of both stage and culture type was never significant. ns: not significant.

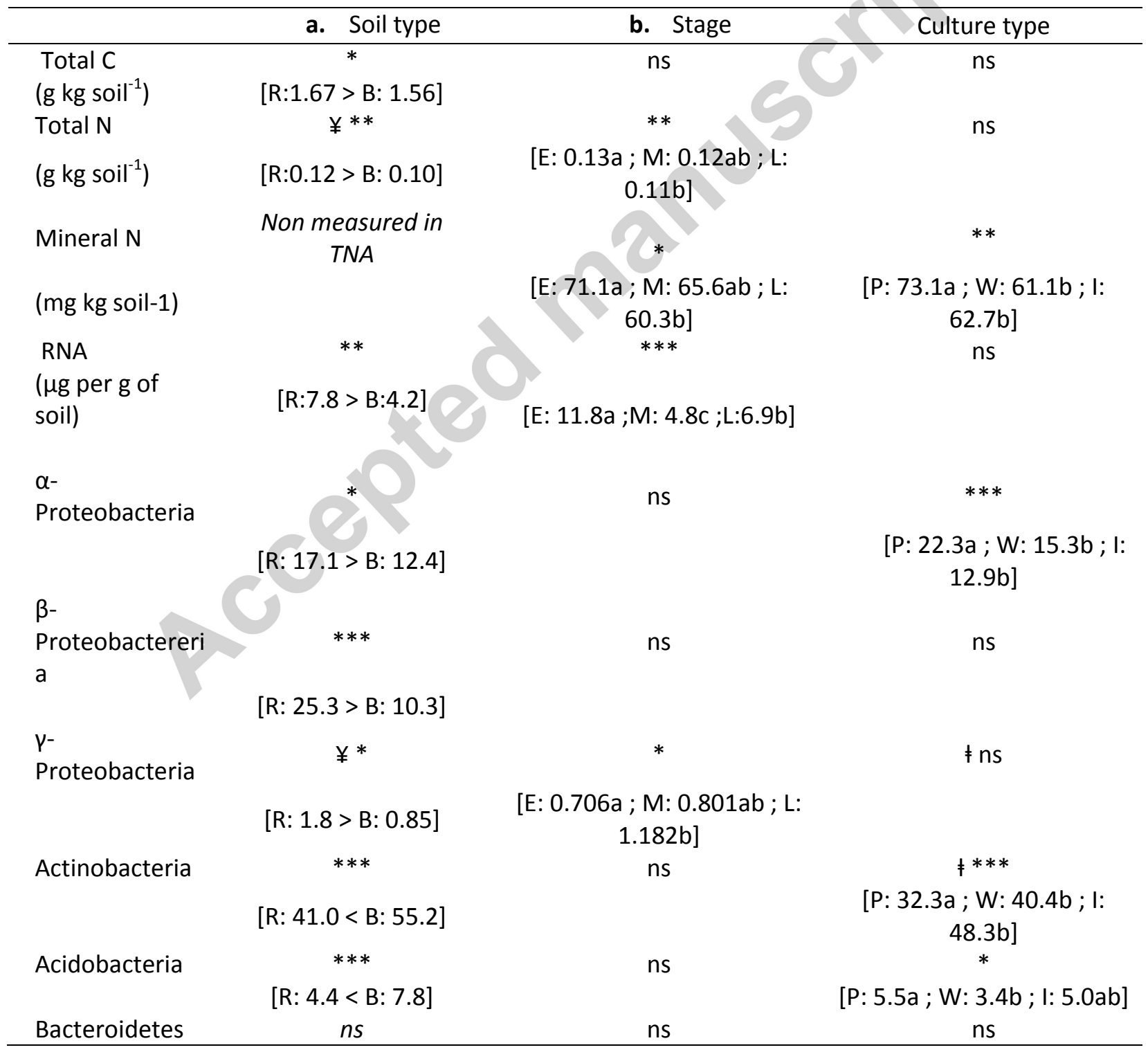




\begin{tabular}{|c|c|c|c|}
\hline \multicolumn{4}{|c|}{ 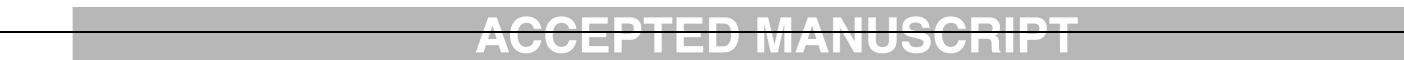 } \\
\hline Firmicutes & $* * *$ & ns & ns \\
\hline & {$[\mathrm{R}: 3.5<\mathrm{B}: 5.6]$} & & \\
\hline
\end{tabular}

$¥$ values were normalized by the In function; $¥$ values were fitted against a Gaussian model.

P.values

$<0.05 ;^{* *}<0.01 ; * * *<0.001$

Figure 1 Biplot representation of the principal component analysis (PCA) calculated on the relative abundance (\%) of seven bacterial phylogenetic groups variables. Total $\mathrm{N}$, total $\mathrm{C}$ and total amount of RNA were inserted in the analysis as quantitative supplementary variables (dashed arrows). Samples are represented with grey shades for the culture type (Pea, Wheat and Intercropping) and different signs sampling stages (early, medium and late). Barycenters are annotated on the graph. Bulk soil subsamples were added as supplemental individuals (crosses). Variable contributions to the determination of the principal components are indicated according the colour (calculated in percentage as: (var. $\cos 2 * 100) /($ total $\cos 2$ of the component, using R package factoextra'). 


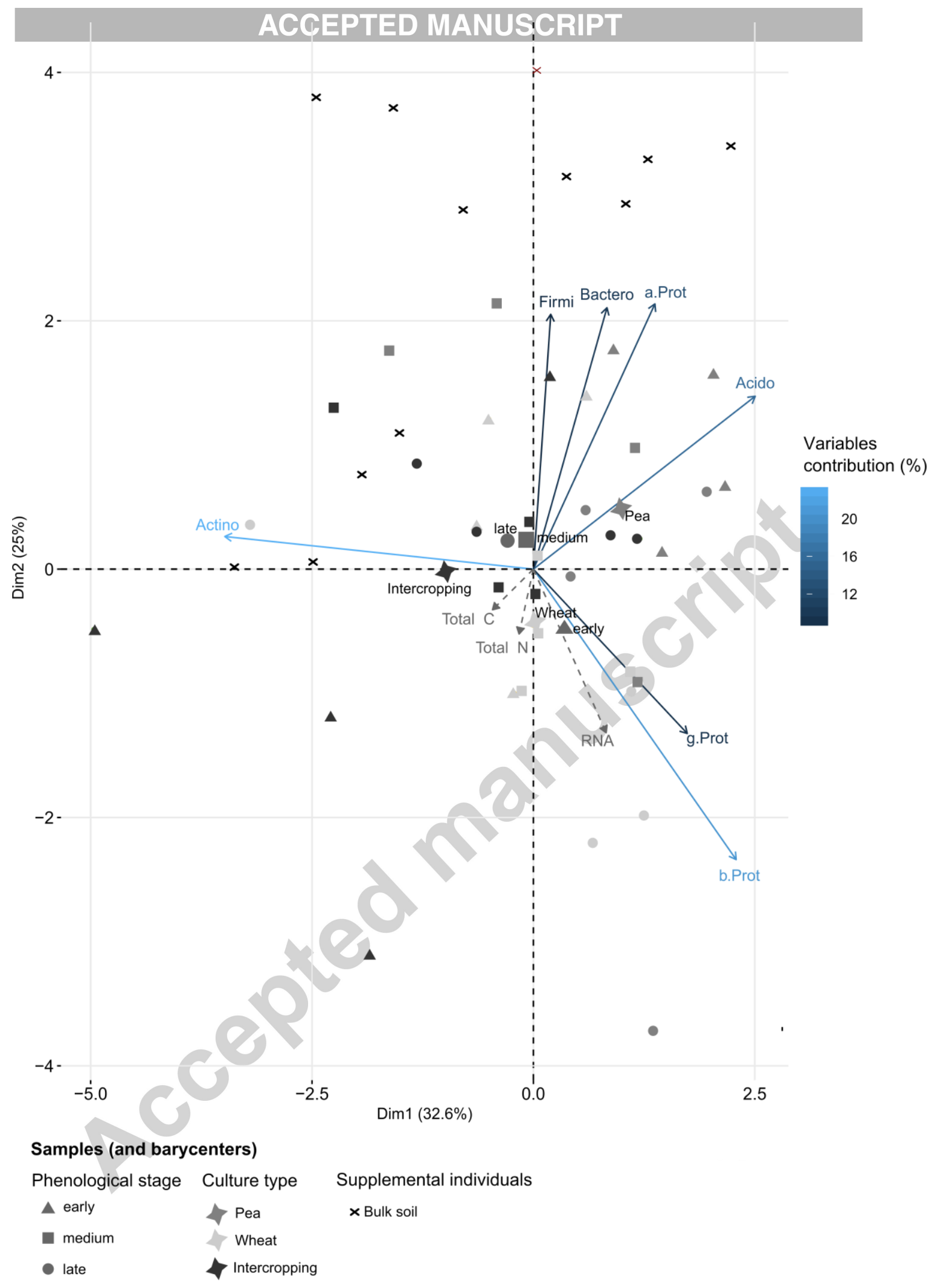

